\title{
In-house method validation and occurrence of alpha-, beta-endosulfan, endosulfan sulphate, lambda-cyhalothrin, procymidone and trifluralin residues in strawberry
}

\author{
Alexandre Augusto SOARES ${ }^{1,2}$, Eliane Hooper AMARAL ${ }^{1}$, Leandro Augusto Ferreira de SOUSA ${ }^{1}$,
} Scheilla Vitorino Carvalho de SOUZA ${ }^{2}$, Roberto Gonçalves JUNQUEIRA²*

\begin{abstract}
A method for determination of organohalogen pesticides in strawberry by gas chromatography with electron capture detection was validated and applied in a monitoring program. Linearity, matrix effects, and day effect were evaluated for the analytes alpha-endosulfan, beta-endosulfan, endosulfan sulphate, lambda-cyhalothrin, procymidone, and trifluralin. The linear range varied according to the chromatographic response of the analyte. Significant matrix effects were observed. The mean recoveries ranged from 74.6 to $115.4 \%$, with repeatability standard deviations between 1.6 and $21.0 \%$ and intermediate precision between 5.9 and $21.0 \%$. Detection, quantification and decision limit, and detection capacity ranged from 0.003 to $0.007 \mathrm{mg} / \mathrm{kg}, 0.005$ to $0.013 \mathrm{mg} / \mathrm{kg} ; 0.003$ to $3.128 \mathrm{mg} / \mathrm{kg}$; and 0.005 to $3.266 \mathrm{mg} / \mathrm{kg}$, respectively. The method was fit for the purpose of monitoring organohalogen residues in strawberries. Residues of these pesticides were detected in 124 of the 186 samples analyzed between 2009 and 2011 in the state of Minas Gerais. Nine of them did not comply with the current legislation requirements; among them, seven $(3.8 \%)$ had residues of unauthorized pesticide for the culture of strawberry, one $(0.5 \%)$ had residues above the maximum residue limit, and another one (0.5\%) exhibited both non-conformities.
\end{abstract}

Keywords: gas chromatography with electron capture detection; organohalogen pesticides; monitoring program.

\section{Introduction}

The increase in world's population and in demand for food has motivated the use of large amounts of pesticides on crops to prevent or control pests in order to ensure higher productivity. Several chemical classes of pesticides have been used to improve the quality of agricultural production, which is strongly affected by undesirable forms of life such as insects and weeds (SANCHES et al., 2003). The role of pesticides in agriculture includes production and productivity increase, product quality improvement, and labor and energy cost reduction. Although these objectives have been achieved in recent decades, the indiscriminate use of these compounds causes serious health and environment problems (KRISTENSON et al., 2001; PINHO et al., 2009).

According to the Brazilian National Health Surveillance Agency - ANVISA (AGÊNCIA..., 2008), the use of pesticides in agricultural production and the consequent contamination of foods have been the subject of public health concern. Due to the toxicological effects caused by pesticides, it is necessary to monitor and quantify the residues of these chemicals in water (VIEIRA; NEVES; QUEIROZ, 2007), soil, food (AMARAL, 2007; GORENSTEIN, 2008; BERRADA et al., 2010) and in the atmosphere as a prerequisite for traceability and protection of the human health and the environment. Residues of pesticides have been found in foods often consumed raw by the population (UNITED..., 2009; SSEBUGERE et al., 2010).
In Brazil, there is the Program for the Analysis of Pesticides in Food (PARA) of ANVISA, which aims to continually evaluate the levels of pesticide residues in fresh food that are consumed in natura by the population, strengthening the government's ability to assure food security, thus avoiding possible health risks to the population (AGÊNCIA..., 2008). There is also the National Program for Control of Residues and Contaminants (PNCRC), of the Ministry of Agriculture, Livestock and Supply (MAPA), which aims to systematize the control of products of animal and vegetal origin with respect to their contamination by compounds that are used in agriculture, including pesticides (BRASIL, 2010a, b, c). In the state of Minas Gerais, this control in fruits and vegetables is carried out by the Minas Gerais Institute of Agriculture (IMA). IMA is a state company responsible for taking care of the sanitary and phytosanitary issues in Minas Gerais State. Its role includes the control of animal and plants transit, compulsory vaccination campaigns, pesticides and veterinary drug products, among others. In summary, IMA's mission is to establish procedures and control the status of animal and plant diseases in the state helping to provide food safety to the consumers.

The organohalogens are one of the most important groups of insecticides used in Brazil; therefore, the analysis of residues of these pesticides in food is essential. Considering the ANVISA program, 128 samples of strawberry were analyzed in 2009, and $50.8 \%$ had unsatisfactory results (unauthorized pesticide

Received 12/27/2012

Accepted 10/14/2013 (005978)

Laboratório de Análises de Resíduos e Agrotóxicos - LARA, Laboratório de Química Agropecuária - LQA, Instituto Mineiro de Agropecuária - IMA, Belo Horizonte, $M G$, Brasil

${ }^{2}$ Programa de Pós-graduação em Ciência de Alimentos - PPGCA, Faculdade de Farmácia - FAFAR, Universidade Federal de Minas Gerais - UFMG,

Av. Antônio Carlos, 6627, Campus da UFMG, Pampulha, CEP 31270-010,Belo Horizonte, MG, Brasil, e-mail: rjunqueira@ufmg.br

${ }^{*}$ Corresponding author 
or residues detected in levels above those permitted). In 2010, 112 strawberry samples were analyzed, among which $63 \%$ had unsatisfactory results (AGÊNCIA..., 2010, 2011). In the context of the PNCRC of the MAPA, for the 2009/2010 and 2010/2011 harvest, around $36.0 \%$ of non-conformities were reported for a total of 75 samples (BRASIL, 2010b, 2011a). Therefore, strawberry stands out as an important commodity to be monitored due to the high frequency of pesticide residues.

Analytical methods for the determination of residues of organohalogen pesticides are based on the use of chromatographic techniques, especially gas chromatography (GC). Although there are several detection systems available, the electron capture detector (ECD) is suitable for their quantitative analysis due to the presence of one or more halogens in the organohalogen molecules (CHEN; WANG, 1996; COLUMÉ et al., 2001; LENTZA-RIZOS; AVRAMIDES; VISI, 2001; VIEIRA; NEVES; QUEIROZ, 2007; ZAWIYAH et al., 2007; PINHO et al., 2009; MENEZES; SANTOS; PEREIRA, 2010).

The growing need for reliable and comparable analytical data is essential for the elimination of technical barriers between countries. Therefore, in order for the measurement to be accepted in other countries, accreditation and legal requirements must be observed. Accordingly, the international standards for quality management systems highlight the importance of a validation method to verify their fitness-forpurpose and ensure reliability of results (ASSOCIAÇÃO..., 2005). Thus, validation is a fundamental requirement of quality management (THOMPSON; ELLISON; WOOD, 2002), which ensures that an analytical method provides reliable results supporting decision making (RIBANI et al., 2004). Therefore, this study presents the validation of a method for detection of alpha-endosulfan, beta-endosulfan, endosulfan sulphate, lambda-cyhalothrin, procymidone, and trifluralin in strawberry by GC-ECD and its application in the IMA monitoring activities in the state of Minas Gerais between 2009 and 2011.

\section{Materials and methods}

\subsection{Samples}

For the validation experiments, strawberry samples were obtained from organic certified cultures. The samples were previously tested, and the absence of signals in the retention time of the studied analytes was confirmed. The samples destined for occurrence investigation were collected on rural properties by IMA fiscals in Alfredo Vasconcelos, Barbacena, Estiva, Pouso Alegre e Bom Repouso, the most important strawberry producers in Minas Gerais state between 2009 and 2011. Sampling was carried out according the Codex Alimentarius (1999) recommendations. At least $1 \mathrm{~kg}$ of strawberries was collected per sample, which were packaged into plastic bags, sealed, labelled, and immediately sent to the laboratory. Only those, for which the period between sampling and the arrival in the laboratory was not longer than $36 \mathrm{~h}$, were selected for analysis.

The samples were homogenized and processed without the sepals, packaged into plastic bags, sealed, labelled and kept frozen between $-25^{\circ} \mathrm{C}$ and $-15{ }^{\circ} \mathrm{C}$ until analyses.

\subsection{Reagents and standards}

The standards of the analytes allethrin, bifenthrin, vinclozolin and fipronil were supplied by Sigma-Aldrich (Seelze, Germany); cyfluthrin (I, II, III, IV), cypermethrin (cis and trans), aldrin, captan, cyproconazole, difenoconazole, dicofol, folpet, iprodione, bromopropilate, chlorotalonil, procloraz, and propiconazole were supplied by ChemService (West Chester, USA); deltamethrin, esfenvalerate, fenvalerate, lambda-cialothrin, cis-permethrin, trans-permethrin, dichlorodiphenyltrichloroethane (DDT) methabolites op'DDD, pp'DDD, op'DDT, pp'DDT, op'DDE, pp'DDE, dieldrin, dodecachloro, alpha-endosulfan, beta-endosulfan, endosulfan sulphate, endrin, hexachlorobenzene (HCB), alpha-hexachlorocyclohexane $(\mathrm{HCH})$, beta- $\mathrm{HCH}$, delta- $\mathrm{HCH}$, lindane (gama-HCH), heptachlor, methoxyclor, procymidone, chlorfenapyr, tetradifon, and trifluralin were supplied by Dr. Ehrenstorfer GmbH (Augsburg, Germany).

Acetone, dichlorometane, $n$-hexane, and sodium sulphate used in the pesticide residues analysis (PRA grade) were purchased from Tedia (Ohio, USA). Acetone PRA was supplied by Vetec (Rio de Janeiro, Brazil), isooctano by PRA by Merck (Darmstadt, Germany), and the ultra-pure gases helium and nitrogen by IBG (São Paulo, Brazil).

\subsection{Analytical procedure}

The analytical procedure was adapted from Netherlands (1996). Aliquots of $15.00 \pm 0.10 \mathrm{~g}$ of previously homogenized and processed strawberry samples and $15 \pm 1 \mathrm{~g}$ of sodium sulphate were weighed into $400 \mathrm{~mL}$ flasks and mixed. Extraction was carried out with $40 \mathrm{~mL}$ of acetone for $30 \mathrm{~s}$, followed by 60 $\mathrm{mL}$ of dichlorometane:n-hexane $(1: 1 \mathrm{v} / \mathrm{v})$ for $30 \mathrm{~s}$ using an ultra turrax homogenizer (Marconi, MA102E). The mixture was filtrated, and the volume was completed with dichlorometane:nhexane $(1: 1 \mathrm{v} / \mathrm{v})$ to $100 \mathrm{~mL}$. An aliquot of $5 \mathrm{~mL}$ of the extract was evaporated to dryness in a rotatory evaporator (Büchi, KRVRTD65/45 and W240N) and re-dissolved with $2 \mathrm{~mL}$ of n-hexane.

GC/ECD analyses were performed on a Varian CP3800 GC equipped with an autosampler CP8200 and a CP-SIL 19CB column ( $14 \%$ cyanopropylphenyl and $86 \%$ dimethylpolysiloxane, $30 \mathrm{~m}$ lengthx $0.25 \mathrm{~mm}$ internal diameter $\times 0.25 \mu \mathrm{m}$ particle size; Varian, Santa Clara, USA). The optimized chromatographic conditions were: helium flow rate of $1.0 \mathrm{~mL} / \mathrm{min}$; injection mode split with a $1 / 20$ rate; injector temperature of $250^{\circ} \mathrm{C}$; ECD temperature: $300^{\circ} \mathrm{C}$; the initial temperature of the column was $70^{\circ} \mathrm{C}$ and was maintained for 1 minute, increased $30^{\circ} \mathrm{C} / \mathrm{min}$ until $180^{\circ} \mathrm{C}$ and maintained for 2 minutes, increased $15^{\circ} \mathrm{C} /$ min until to $250^{\circ} \mathrm{C}$ and was maintained for 8 minutes, it was finally increased $15^{\circ} \mathrm{C} / \mathrm{min}$ until $280^{\circ} \mathrm{C}$ and maintained for 17 minutes. The total run time was 35 minutes. Confirmation was carried out under the same chromatographic conditions with a CP-SIL 5CB column (100\% dimethylpolysiloxane, $30 \mathrm{~m} \times$ $0.25 \mathrm{~mm}$ i.d. $\times 0.25 \mu \mathrm{m}$ particle size; Varian, Santa Clara, USA).

\subsection{Validation}

The performance characteristics of the method were established by in-house validation procedures employing assays 
with standard solutions, sample blanks, and spiked samples. The analytes chosen for the validation studies were endosulfan (alpha, beta and sulphate), lambda-cyhalothrin, procymidone, and trifluralin because they were representative of organochlorines, pyrethroids, dicaboximides, and dinitroanilines herbicides, respectively (AGÊNCIA..., 2008, 2010, 2011).

Selectivity, linearity, matrix and day effects, recovery, precision, detection limit (LD), quantification limit (LQ), decision limit (CCa), and detection capability (CC $\beta$ ) were investigated as described by Souza (2007). This validation procedure was in accordance with the International Standards Organization (ISO), International Union of Pure and Applied Chemistry (IUPAC) and Association of Official Analytical Chemists (AOAC), and international harmonized protocol (THOMPSON; ELLISON; WOOD, 2002); they were referred in Brazilian guidelines related to method validation (INSTITUTO..., 2010; BRASIL, 2011b). Linearity was assessed by linear regression based on the procedure proposed by Souza and Junqueira (2005) in the range from 1.0 to $9.0 \mathrm{ng} / \mathrm{mL}$ for alpha-endosulfan, from 2.0 to $24.0 \mathrm{ng} / \mathrm{mL}$ for trifluralin and beta-endosulfan, and from 3.0 to $45.0 \mathrm{ng} / \mathrm{mL}$ for endosulfan sulphate, lambda-cyhalothrin, and procymidone. The evaluation of the day effect was based on the calibration curves generated from the linearity study and obtained in three different days. The slopes and interceptions were compared by the t test, applying two orthogonal contrasts (AMARAL, 2007). Matrix effects were assessed by the method of standard additions. Two calibration curves were prepared; one of them was prepared in n-hexane (usual curve) and the other one in extracts of the studied matrix (matrix-matched curve). The slope, intercept, and the respective variances of both curves were calculated by OLSM. All assumptions were tested, and linearity was also assessed for these curves. The slopes and interceptions obtained from the solvent and matrix-matched calibration curves were compared for significant differences by the Student's t test. For recovery and precision under repetitivity and intermediate precision conditions studies, blank and spiked samples were prepared at five levels in the linear range, with twelve independent replicates for each level, which were divided into four analytical batches to obtain the intermediate precision conditions. Lack of trueness was investigated through mean recovery obtained for twelve replicates of spiked samples at $0.005,0.008$ and $0.019 \mathrm{mg} / \mathrm{kg}$ for alpha-endosulfan; $0.005,0.011$ and $0.032 \mathrm{mg} / \mathrm{kg}$ for betaendosulfan and trifluralin; and $0.013,0.032$ and $0.107 \mathrm{mg} / \mathrm{kg}$ for endosulfan sulphate, lambda- cyhalothrin and procymidone. The replicates were divided into four analytical batches, which were analyzed on different days by different analysts. Precision, under repeatability and intermediate precision conditions were estimated by ANOVA and expressed in terms of relative standard (RSD) deviation for each level. The criteria for the acceptability of mean recovery and the relative standard deviations obtained under repeatability $\left(\mathrm{RSD}_{\mathrm{r}}\right)$ and intermediate precision $\left(\mathrm{RSD}_{\mathrm{R}}\right)$ conditions were based on European Commission (2010). The LQ was stated as a concentration below which the method could not operate with an acceptable precision and trueness. The LD was the lowest concentration of the organohalogens in strawberry samples that was detectable, but not necessarily quantified and distinguished from zero (signal / noise $\geq 3$ ).
These limits were established based on the mean recovery and relative standard deviation results obtained for the replicates of spiked samples. CC $\alpha$ and CC $\beta$ were estimated using the recovery results obtained in the intermediate precision experiments, and the maximum residues limits (MRL) established by the national legislation according the statistical procedure described by Van Loco and Beernaert (2003).

\subsection{Occurrence}

186 strawberries samples were analyzed, 94 in 2009, 75 in 2010, and 17 in 2011. 46 organohalogens were investigated by the validated method, including the pyrethroids allethrin, bifenthrin, cyfluthrin (I, II, III, IV), cypermethrin (cis and trans), deltamethrin, esfenvalerate, fenvalerate, lambda-cialothrin, cis-permethrin and trans-permethrin; the organochlorines aldrin, op'DDD, pp'DDD, op'DDT, pp'DDT, op'DDE, pp'DDE, dicofol, dieldrin, dodecachloro, alpha-endosulfan, betaendosulfan, endosulfan sulphate, endrin, $\mathrm{HCB}$, alpha- $\mathrm{HCH}$, beta- $\mathrm{HCH}$, delta-HCH, lindane, heptachlor, and methoxyclor; the fungicides triazole cyproconazole, difenoconazole, and propiconazole; the fungicides dicarboximides captan, folpet, iprodione, procymidone, and vinclozolin; and other classes such as bromopropilate, chlorfenapyr, chlorotalonil, fipronil, procloraz, tetradifon, and trifluralin.

\section{Results and discussion}

\subsection{Validation}

\section{Selectivity}

The mean retention times and peak resolution obtained for the organohalogens studied, considering 27 runs, are described in Table 1. The minimal value estimated for the peak resolution was 1.5 , considering all of the analytes, which was satisfactory according to the Kealey and Haines (2002) criteria. The resolution indicated the ability of the method to determine all organohalogens tested without mutual interference between the analytes, even for the pairs of isomers of lambda-cyhalothrin. Typical chromatograms of blank samples, standard solution of the organohalogens prepared in solvent, standard solution of the organohalogens prepared in strawberry extracts and spiked samples are shown in Figure 1. In all cases, the peaks in the

Table 1. Retention times and peak resolution obtained for the studied organohalogens.

\begin{tabular}{ccc}
\hline Analyte & Retention time $(\mathrm{min})^{\star}$ & Resolution $(\mathrm{R})^{\star}$ \\
\hline Trifluralin & $9.865 \pm 0.009$ & 54.0 \\
Procymidone & $13.918 \pm 0.014$ & 79.7 \\
Alpha-endosulfan & $14.490 \pm 0.011$ & 10.8 \\
Beta-endosulfan & $15.481 \pm 0.013$ & 17.8 \\
Endosulfan sulphate & $16.447 \pm 0.013$ & 15.9 \\
Lambda-cyhalothrin I & $20.079 \pm 0.027$ & 44.3 \\
Lambda- cyhalothrin II & $20.586 \pm 0.030$ & 4.9 \\
\hline
\end{tabular}

${ }^{*}$ means of 27 runs, $\mathrm{R}=2 \Delta \mathrm{t}_{\mathrm{r}} /\left(\mathrm{W}_{\mathrm{l}}+\mathrm{W}_{2}\right), \Delta \mathrm{t}_{\mathrm{r}}$ is the variation of the retention time between two peaks and $\mathrm{W}$ the width of the peaks baseline. 
chromatograms of the spiked samples were sharp and similar to those of the standard solution of comparable concentrations.

All blank samples analyzed showed non-detected results for SEM (signal / noise < 3). Cardoso et al. (2010) also evaluated
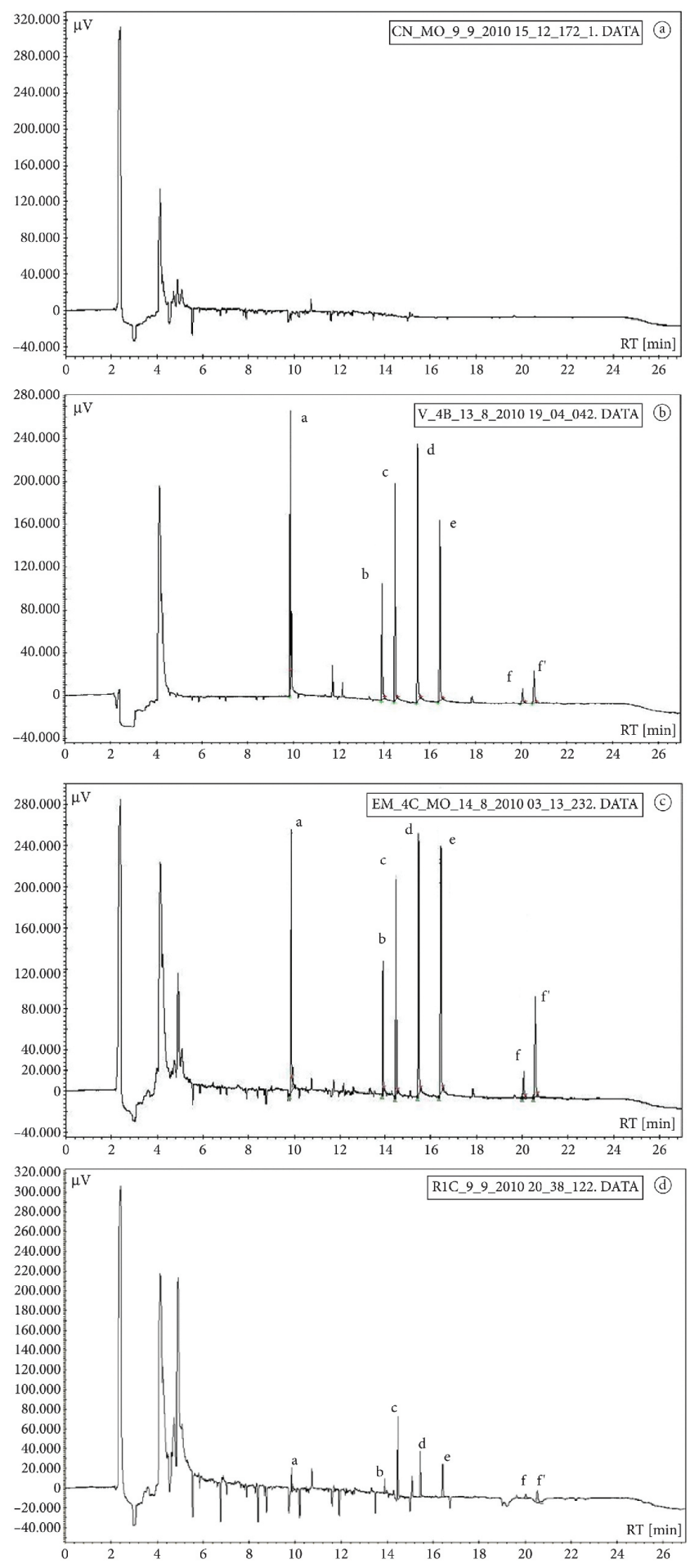

Figure 1. Typical chromatograms obtained for (a) blank sample, (b) standard solution of the organohalogens in hexane, (c) standard solution of the organohalogens prepared in strawberry extracts and (d) spiked sample. (a) Trifluralin, (b) Procymidone, (c) Alpha-endosulfan, (d) Beta-endosulfan, (e) Endosulfan sulphate, (f) Lambda-cyhalothrin I e (f') Lambda-cyhalothrin II. selectivity by the analysis of spiked samples with the pesticides gama-HCH, chlorotalonil, fenitrothion, chlorpyrifos, and procymidone in tomato.

\section{Linearity}

The statistics obtained for the linearity assessment is shown in Table 2. The outliers detected by the Jacknife residuals were removed. The assumptions that the errors are normally distributed, homoscedastic, and independent were confirmed. The high significance $(\mathrm{p}<0.001)$ of the regression, although the lack of fit was not significant ( $p>0.05)$, indicated linearity in the range from 2.0 to $7.0 \mathrm{ng} / \mathrm{mL}$ (corresponding to 0.005 to 0.019 $\mathrm{mg} / \mathrm{kg}$ of strawberry) for alpha-endosulfan, from 2.0 to 17.0 $\mathrm{ng} / \mathrm{mL}$ (corresponding to 0.005 to $0.032 \mathrm{mg} / \mathrm{kg}$ of strawberry) for trifluralin and beta-endosulfan, and from 5.0 to $40.0 \mathrm{ng} /$ $\mathrm{mL}$ (corresponding to 0.013 to $0.1079 \mathrm{mg} / \mathrm{kg}$ of strawberry) for endosulfan sulphate, lambda-cyhalothrin, and procymidone. The linearity assessment over three different days indicated that the regression parameters were stable only for beta-endosulfan and trifluralin. For the other analytes studied, the curves did not show the same chromatographic responses (Table 3). These results confirmed those obtained by Amaral (2007), in which the calibration response obtained for pesticides, even for solutions prepared in solvents, cannot be reused for the quantification in different days.

\section{Matrix effects}

When the slopes and interceptions from the solvent standard curves were compared with those from strawberry matrix-matched curves, significant differences $(p<0.05)$ were observed, demonstrating that the chromatographic response of the analytes was affected by the presence of the matrix (Figure 2).

For the organohalogens endosulfan sulphate and lambdacyhalothrin, there were significant differences $(\mathrm{p}<0.001)$ between the slopes, while differences between the interceptions were observed for alpha-endosulfan $(\mathrm{p}<0.05)$. For the other studied analytes, there were no significant matrix effects $(\mathrm{p}>$ 0.05 ) in the respective concentration ranges. As for lambacyhalothrin, considering that the residual variances of the matrix matched and solvent calibration curves were heteroscedastic ( $p$ $<0.01$ ), the comparison between slopes and interceptions was carried out by the t test (Table 4). Based on these results, it was possible to conclude that matrix matched curves need to be used to calculate organohalogen concentrations in strawberry samples.

According to González et al. (2002), effects on the slope cause proportional systematic error in the quantification, while constant systematic errors are observed when the interception is affected by the presence of the matrix. Ambrus (2000) states that the matrix effects vary from day to day during the regular use of the method, depending on the conditions of the GC system and the type of injection. This means that the preliminary assessment of the matrix effects for the method validation is not sufficient. This parameter should be continuously assessed when the option is the use of usual calibration curves in the absence of the matrix. As demonstrated in this paper, the 
Table 2. Linearity assessment for standard solutions of the organohalogens prepared in hexane in three different days.

\begin{tabular}{|c|c|c|c|c|c|c|c|}
\hline \multirow{2}{*}{$\begin{array}{l}\text { Analyte } \\
\text { (Range) }\end{array}$} & \multirow{2}{*}{ Day } & \multicolumn{6}{|c|}{ Statistic } \\
\hline & & $\mathrm{n}$ & $\mathrm{R}$ & $\mathrm{d}$ & $t_{L}$ & $\mathrm{~F}_{\text {Regression }}$ & $\mathrm{F}_{\text {Lack-of-fit }}$ \\
\hline \multirow{3}{*}{$\begin{array}{l}\text { Alpha-endosulfan } \\
(2.0 \text { to } 7.0 \mathrm{ng} / \mathrm{mL})\end{array}$} & 1 & 16 & 0.9739 & 2.177 & 0.695 & 576.8 & 1.642 \\
\hline & 2 & 16 & 0.9646 & 1.842 & 0.799 & 518.2 & 0.880 \\
\hline & 3 & 17 & 0.9927 & 1.633 & 1.630 & 1688.7 & 1.42 \\
\hline \multirow{2}{*}{$\begin{array}{l}\text { Beta-endosulfan } \\
(2.0 \text { to } 17.0 \mathrm{ng} / \mathrm{mL})\end{array}$} & 1 & 18 & 0.9744 & 2.367 & 0.425 & 813.6 & 1.252 \\
\hline & 2 & 18 & $0.9564^{\#}$ & 1.224 & 0.454 & 367.6 & 2.569 \\
\hline \multirow{2}{*}{$\begin{array}{l}\text { Endosulfan sulphate } \\
\text { (5.0 to } 40.0 \mathrm{ng} / \mathrm{mL} \text { ) }\end{array}$} & 2 & 14 & 0.9847 & 2.334 & 1.052 & 563.7 & 0.819 \\
\hline & 3 & 16 & 0.9750 & 2.453 & 0.022 & 227.0 & 1.715 \\
\hline \multirow{3}{*}{$\begin{array}{l}\text { Lambda-cyhalothrin } \\
\text { ( } 5.0 \text { to } 40.0 \mathrm{ng} / \mathrm{mL} \text { ) }\end{array}$} & 1 & 16 & 0.9633 & 1.900 & 1.951 & 265.1 & 1.901 \\
\hline & 2 & 14 & 0.9762 & 2.535 & 1.700 & 380.0 & 0.321 \\
\hline & 3 & 15 & 0.9816 & 1.602 & 0.415 & 429.8 & 2.465 \\
\hline \multirow{3}{*}{$\begin{array}{c}\text { Trifluralin } \\
(2.0 \text { to } 17.0 \mathrm{ng} / \mathrm{mL})\end{array}$} & 1 & 18 & 0.9773 & 2.322 & 0.285 & 1543.4 & 0.411 \\
\hline & 2 & 18 & 0.9581 & 1.997 & 0.558 & 1450.4 & 2.734 \\
\hline & 3 & 15 & 0.9839 & 1.507 & 0.181 & 1336.1 & 3.361 \\
\hline
\end{tabular}

n: number of observations after the outliers treatment by Jack-Knife residual test $(\mathrm{p}<0.05), \mathrm{R}$ : Ryan-Joiner correlation coefficient $\left(\mathrm{p}>0.10\right.$ or ${ }^{\#} \mathrm{p}>$ 0.05), d: Durbin-Watson statistic ( $p>0.10)$, tL: Levene t statistic ( $p>0.05), \mathrm{F}_{\text {Regression }}$ : variance ratio $(\mathrm{p}<0.001)$, $\mathrm{F}_{\text {Lack-of-fit }}$ : variance ratio $(\mathrm{p}>0.05)$.

Table 3. Evaluation of the day effect based on the calibration curves of the organohalogens prepared in hexane in three different days.

\begin{tabular}{|c|c|c|c|c|c|c|}
\hline \multirow[t]{2}{*}{ Statistic } & \multicolumn{6}{|c|}{ Analyte } \\
\hline & Alpha-endosulfan & Beta-endosulfan & $\begin{array}{c}\text { Endosulfan } \\
\text { sulphate }\end{array}$ & $\begin{array}{c}\text { Lambda- } \\
\text { cyhalothrin }\end{array}$ & Procymidone & Trifluralin \\
\hline \multicolumn{7}{|c|}{ Slope } \\
\hline$t_{(Y 2 b)}$ & 1.567 & 0.9772 & 0.1531 & $7.139^{* * *}$ & $2.351^{*}$ & 0.7036 \\
\hline \multicolumn{7}{|c|}{ Interception } \\
\hline$t_{(Y 1 a)}$ & $4.333^{\star * *}$ & 1.256 & 0.2475 & 0.0867 & 0.1060 & 0.1060 \\
\hline$t_{(\mathrm{Y} 2 \mathrm{a})}$ & $5.016^{* * *}$ & 0.6224 & 0.6430 & 1.046 & 0.9093 & 0.9093 \\
\hline
\end{tabular}

Table 4. Slope and intercept comparisons between strawberry matrix matched and solvent (hexane) calibration curves.

\begin{tabular}{|c|c|c|c|c|c|c|}
\hline \multirow{2}{*}{ Statistic } & \multicolumn{6}{|c|}{ Analyte } \\
\hline & Alpha-endosulfan & Beta-endosulfan & Endosulfan sulphate & Lambda- cyhalothrin & Procymidone & Trifluralin \\
\hline \multicolumn{7}{|c|}{ Homoscedasticity } \\
\hline $\mathrm{F}$ & 2.369 & 2.233 & 1.407 & $5.238^{\star *}$ & 2.021 & 1.286 \\
\hline $\mathrm{t}_{(\mathrm{Yb})}$ & 1.670 & 0.1642 & $5.161^{* * *}$ & $9.939^{* * *}$ & 1.752 & 1.195 \\
\hline \multicolumn{7}{|c|}{ Interception } \\
\hline
\end{tabular}

chromatographic response was affected by the day of analysis, even in the absence of the matrix (Table 3). The matrix effect has been attributed primarily to the presence of components in the sample that may be adsorbed in the active sites of the injector and change the behavior of the analytes in the vaporization chamber. Consequently, the amount of analyte reaching the column in extracts containing the matrix can be different from the amount injected in pure solvent. Therefore, the matrix effects can generate analytical problems due to the possible overestimation or underestimation of the analyte concentration (ZROSTLÍKOVÁ et al., 2001; ANASTASSIADES et al., 2003; POOLE, 2007; PINHO et al., 2009).

Przybylski and Hommet (2008) compared the slope of calibration curves obtained from standard solutions prepared with 12 pesticides in solvent and in extracts of carrot baby 
(a)

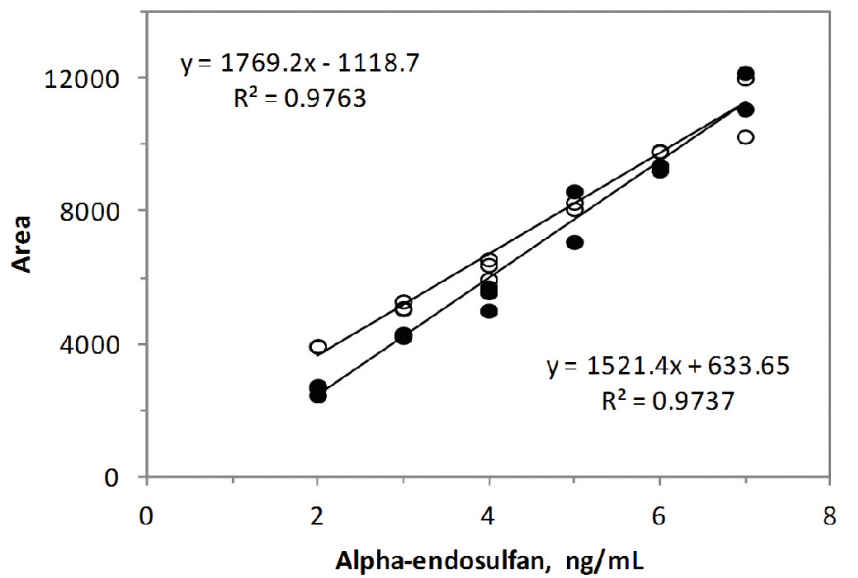

- Hexane o Matrix

(c)

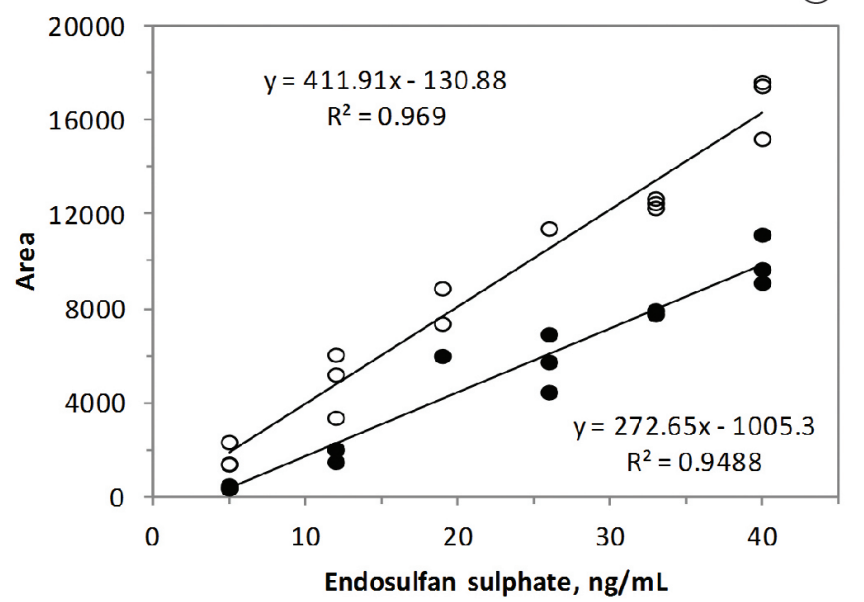

- Hexane O Matrix

(e)

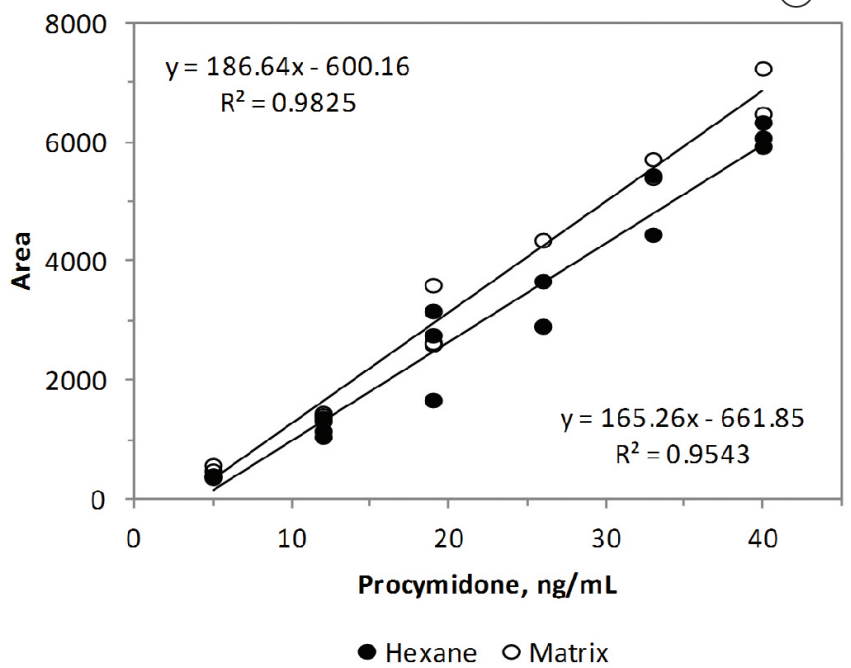

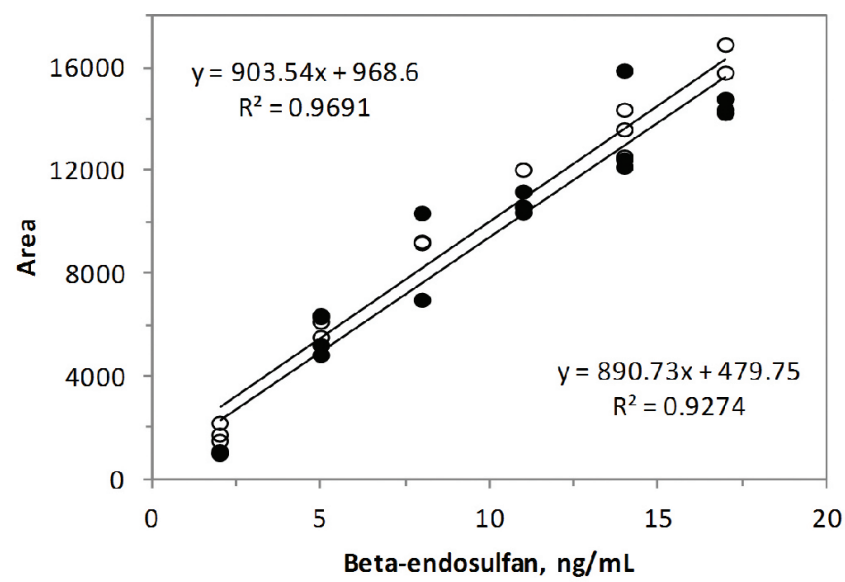

- Hexane O Matrix

(d)

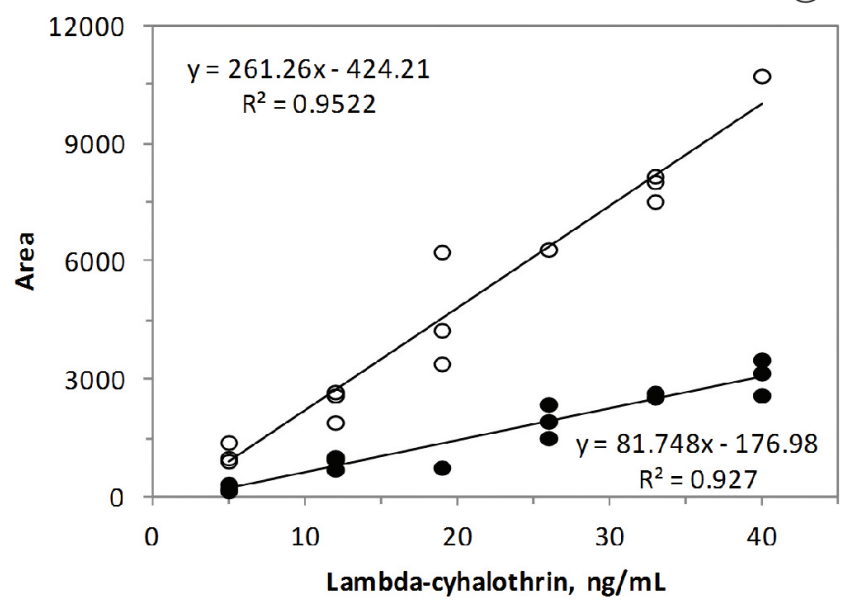

- Hexane o Matrix

(f)

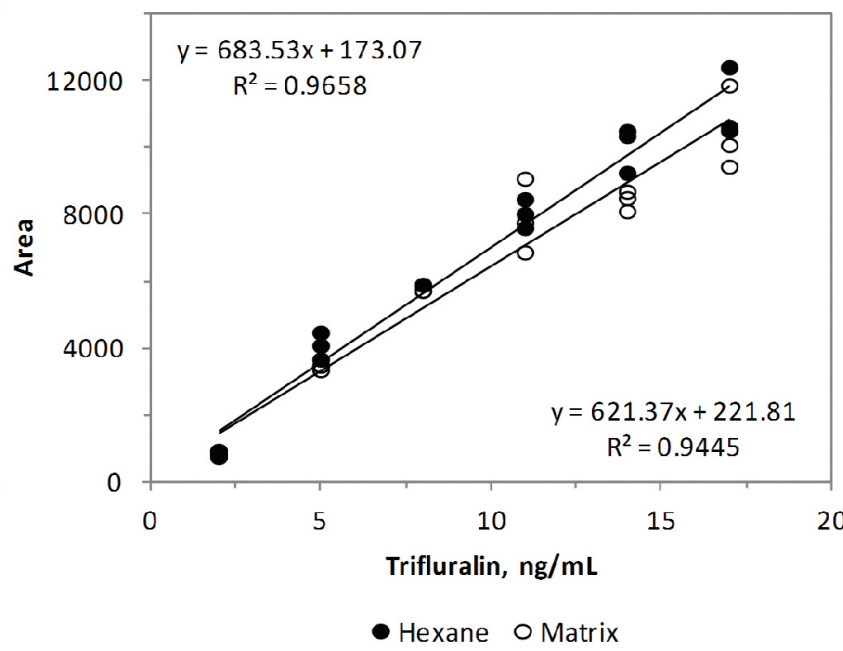

Figure 2. Comparison between solvent (hexane) and strawberry matrix matched calibration curves for the studied organohalogens.

food, beans, potatoes, and peas. The results indicated that the matrix effects may be positive or negative, depending on the characteristics of the pesticide and the complexity of the matrix being analyzed by GC. Cardoso et al. (2010) tested the matrix effects for five pesticides and confirmed these effects for chlorpyrifos and fenitrothion, while for the gamma $\mathrm{HCH}$, procymidone, and chlorothalonil no significant effects of the matrix were observed, confirming the results obtained in the present study, in which no matrix effects were detected for procymidone. In general, hydrophobic compounds, such as 
organochlorine pesticides, do not create pronounced matrix effects due to the fact that they are less susceptible to adsorption by active sites of the injector (PINHO et al., 2009). Although the pyrethroids are less polar than organochlorines, they have significant matrix effects due to their high molecular weight (above $400 \mathrm{~g} / \mathrm{mol}$ ), which hinders volatilization and consequently produces smaller signals. In the present study, the matrix effect of lambda-cyhalothrin, a pyrethroid compound was confirmed, in accordance with the results observed by Pinho et al. (2009). However, among the three organochlorines studied, two showed matrix effects, contradicting the trend indicated by these authors. Matrix effects are complex and are difficult to predict, but pesticides containing functional groups $\mathrm{P}=\mathrm{O}$ (organophosphorus), $-\mathrm{O}-\mathrm{CO}-\mathrm{NH}$-(carbamates), $-\mathrm{OH}$ (hydroxy), - $\mathrm{N}=$ (imidazoles and benzimidazoles),-NH-CO$\mathrm{NH}$-(urea derivatives) are more susceptible to these effects (SCHENCK; LEHOTAY, 2000).

\section{Recovery and precision}

The recovery results were analyzed for the presence of outliers. Acceptable mean recoveries were achieved for all analytes (Table 5). However, estimates of $\mathrm{RSD}_{\mathrm{r}}$ and $\mathrm{RSD}_{\mathrm{R}}$ above $20 \%$ were observed for alpha-endosulfan at the level of $0.005 \mathrm{mg} / \mathrm{kg}$. These results showed no lack of trueness and precision of the validated method in the range of $0.005 \mathrm{mg} /$ $\mathrm{kg}$ to $0.032 \mathrm{mg} / \mathrm{kg}$ for beta-endosulfan and trifluralin, 0.013 $\mathrm{mg} / \mathrm{kg}$ to $0.107 \mathrm{mg} / \mathrm{kg}$ for endosulfan sulphate, procymidone, and lambda-cyhalothrin; and $0.008 \mathrm{mg} / \mathrm{kg}$ to $0.019 \mathrm{mg} / \mathrm{kg}$ for alpha-endosulfan considering the established criteria. The average recovery ranged from $74.59 \%$ to $115.41 \%$, and $\mathrm{RSD}_{\mathrm{r}}$ ranged between $1.63 \%$ and $20.98 \%$ and $\mathrm{RSD}_{\mathrm{R}}$ between $5.86 \%$ and $20.98 \%$. Disregarding the value of $20.98 \%$, that exceeded the limits established by the European Commission (2010); the largest acceptable value of $\mathrm{RSD}_{\mathrm{r}}$ and $\mathrm{RSD}_{\mathrm{R}}$ was $19.91 \%$. These results were similar to those reported in the literature; although, most of them addressed concentration levels higher than those investigated here and carried out precision experiments under repeatability conditions (Table 6).

\section{Limits of detection, quantification, decision, and detection capability}

The limits established in this study, as shown in Table 7, were suitable for monitoring the activities, considering the Brazilian legislation: the maximum MRL of $3 \mathrm{mg} / \mathrm{kg}$ for procymidone and $0.5 \mathrm{mg} / \mathrm{kg}$ for lambda-cyhalothrin and the non-authorized inseticides alpha-, beta-endosulfan and endosulfan sulfate. These estimated LD were similar to those found in the literature. Zawiyah et al. (2007) determined the LD for six organochlorines and three pyrethroids in the range of $0.003 \mathrm{mg} / \mathrm{kg}$ to $0.015 \mathrm{mg} / \mathrm{kg}$ for grape samples, considering signal / noise $\geq 3$. Adopting the same criterion, Cardoso et al. (2010) established LD for tomato samples: $0.006 \mathrm{mg} / \mathrm{kg}$ for chlorothalonil and procymidone; $0.005 \mathrm{mg} / \mathrm{kg}$ for $\mathrm{HCH}$ and fenitrothion; and $0.004 \mathrm{mg} / \mathrm{kg}$ for chlorpyrifos. Menezes, Santos and Pereira (2010) determined $\mathrm{LD}$ for pesticide residues in sleeve samples in the range from $0.001 \mathrm{mg} / \mathrm{kg}$ to $0.033 \mathrm{mg} / \mathrm{kg}$, but they did not describe how the limits were calculated.

The established LQ, which corresponded to the lowest levels that indicated acceptable precision and accuracy, were smaller than those mentioned above; although the method has been validated for a closer range of linearity. Imoto, Fontoura and Freitas (2004) found LQ of $0.02 \mathrm{mg} / \mathrm{kg}$, adopting the criterion

Table 5. Mean recovery and relative standard deviation under repeatability and intermediate precision conditions at the different concentration levels.

\begin{tabular}{|c|c|c|c|c|}
\hline \multirow{2}{*}{ Analyte } & Concentration & MR & $\mathrm{RSD}_{\mathrm{r}}$ & $\mathrm{RSD}_{\mathrm{R}}$ \\
\hline & $(\mathrm{mg} / \mathrm{kg})$ & $(\%)$ & $(\%)$ & $(\%)$ \\
\hline \multirow[t]{3}{*}{ Alpha-endosulfan } & 0.005 & 78.06 & 20.98 & 20.98 \\
\hline & 0.008 & 88.04 & 4.90 & 13.42 \\
\hline & 0.019 & 82.93 & 2.65 & 8.41 \\
\hline \multirow[t]{3}{*}{ Beta-endosulfan } & 0.005 & 88.34 & 9.40 & 17.07 \\
\hline & 0.011 & 92.20 & 6.60 & 12.57 \\
\hline & 0.032 & 81.85 & 1.63 & 6.43 \\
\hline \multirow[t]{3}{*}{ Endosulfan sulphate } & 0.013 & 83.94 & 19.91 & 19.91 \\
\hline & 0.032 & 89.86 & 14.18 & 17.68 \\
\hline & 0.107 & 76.70 & 4.66 & 10.10 \\
\hline \multirow[t]{3}{*}{ Lambda- cyhalothrin } & 0.013 & 115.41 & 4.04 & 13.09 \\
\hline & 0.032 & 81.79 & 6.19 & 13.61 \\
\hline & 0.107 & 74.59 & 12.78 & 12.85 \\
\hline \multirow[t]{3}{*}{ Procymidone } & 0.013 & 101.52 & 4.73 & 13.94 \\
\hline & 0.032 & 82.98 & 6.42 & 7.35 \\
\hline & 0.107 & 85.14 & 3.41 & 10.22 \\
\hline \multirow[t]{3}{*}{ Trifluralin } & 0.005 & 108.93 & 5.86 & 5.86 \\
\hline & 0.011 & 99.89 & 7.33 & 9.23 \\
\hline & 0.032 & 91.65 & 4.15 & 6.08 \\
\hline
\end{tabular}

MR: mean recovery of 12 replicates, $\mathrm{RSD}_{\mathrm{r}}$ : repeatability relative standard deviation, $\mathrm{RSD}_{\mathrm{R}}$ : intermediate precision relative standard deviation, Criteria: $70 \% \leq \mathrm{MR} \leq 120 \%$, $\mathrm{RSD} \leq$ $20,0 \%$ and $\mathrm{RSD}_{\mathrm{R}} \leq 20,0 \%($ EUROPEAN..., 2010). 
Method validation and occurrence of six organohalogens residues in strawberry

Table 6. Mean recovery and relative standard deviation reported in the literature for similar scopes.

\begin{tabular}{|c|c|c|c|c|c|c|c|}
\hline Analyte & Matrix & Technique & $\begin{array}{c}\text { Concentration } \\
(\mathrm{mg} / \mathrm{kg})\end{array}$ & MR (\%) & RSD (\%) & $\mathrm{N}$ & Reference \\
\hline $\begin{array}{l}17 \text { synthetic } \\
\text { pyrethroids, including } \\
\text { lambda-cyhalothrin }\end{array}$ & $\begin{array}{l}14 \\
\text { vegetables and } \\
\text { fruits, including } \\
\text { strawberry }\end{array}$ & $\begin{array}{c}\text { gas } \\
\text { chromatography/ } \\
\text { electron capture } \\
\text { detection }\end{array}$ & 0.02 and 0.10 & $66-102$ & $3-6$ & 6 & $\begin{array}{l}\text { Columé et al. } \\
\qquad(2001)\end{array}$ \\
\hline $\begin{array}{l}\text { Alpha- and beta- } \\
\text { endosulfan, endosulfan } \\
\text { sulphate, lambda- } \\
\text { cyhalothrin and other } 4 \\
\text { pyrethroids }\end{array}$ & olive oil & $\begin{array}{c}\text { gas } \\
\text { chromatography/ } \\
\text { electron capture } \\
\text { detection }\end{array}$ & 0.20 & $71-91$ & $6-17$ & 5 & $\begin{array}{l}\text { Lentza-Rizos, } \\
\text { Avramides and } \\
\text { Visi (2001) }\end{array}$ \\
\hline $\begin{array}{l}8 \text { organohalogen, } \\
\text { including alpha } \\
\text { endosulfan, beta- } \\
\text { endosulfan, endosulfan } \\
\text { sulphate and trifluralin }\end{array}$ & apple & $\begin{array}{c}\text { gas } \\
\text { chromatography/ } \\
\text { electron capture } \\
\text { detection }\end{array}$ & 0.02 and 0.10 & $74-111$ & $5-14$ & 5 & $\begin{array}{c}\text { Imoto, } \\
\text { Fontouraand } \\
\text { Freitas (2004) }\end{array}$ \\
\hline $\begin{array}{l}\text { Multi-residues for } 43 \\
\text { pesticides and } 9 \text { pesticide } \\
\text { metabolites }\end{array}$ & $\begin{array}{l}\text { tomato, lemon, } \\
\text { avocado and } \\
\text { raisins }\end{array}$ & $\begin{array}{l}\text { liquid } \\
\text { chromatography / } \\
\text { mass spectrometry }\end{array}$ & 0.01 and 0.10 & $70-110$ & $<15$ & 5 & $\begin{array}{l}\text { Hernández et al. } \\
\text { (2006) }\end{array}$ \\
\hline $\begin{array}{l}\text { Procymidone and other } 4 \\
\text { halogenated compounds }\end{array}$ & tomato & $\begin{array}{c}\text { gas } \\
\text { chromatography/ } \\
\text { electron capture } \\
\text { detection }\end{array}$ & 0.020 to 2.5 & $72-110$ & $2-15$ & 6 & $\begin{array}{l}\text { Cardoso et al. } \\
\qquad(2010)\end{array}$ \\
\hline 14 organochlorines & $\begin{array}{c}\text { apricot, } \\
\text { nectarine, } \\
\text { cherry, plum, } \\
\text { apple, pear and } \\
\text { quince }\end{array}$ & $\begin{array}{l}\text { gas } \\
\text { chromatography/ } \\
\text { mass spectrometry }\end{array}$ & 0.008 & $71-172$ & $<17$ & 2 & $\begin{array}{l}\text { Cieslik et al. } \\
\text { (2011) }\end{array}$ \\
\hline
\end{tabular}

Table 7. Limits of detection, quantification, decision, and detection capability estimated for the studied organohalogens in strawberry.

\begin{tabular}{ccccc}
\hline Analyte & LD & LQ & CC $\alpha$ & $(\mathrm{mg} / \mathrm{kg})$ \\
\cline { 2 - 5 } & $(\mathrm{mg} / \mathrm{kg})$ & $(\mathrm{mg} / \mathrm{kg})$ & 0.003 & 0.005 \\
\hline Alpha-endosulfan & 0.003 & 0.008 & 0.004 & 0.006 \\
Beta-endosulfan & 0.003 & 0.005 & 0.025 & 0.042 \\
Endosulfan sulphate & 0.007 & 0.013 & 0.538 & 0.581 \\
Lambda- cyhalothrin & 0.007 & 0.013 & 3.128 & 3.266 \\
Procymidone & 0.007 & 0.013 & 0.004 & 0.006 \\
Trifluralin & 0.003 & 0.005 & & \\
\hline
\end{tabular}

LD: limit of detection, LQ: limit of quantifiation, $\mathrm{CC} \alpha$ : decision limit, $\mathrm{CC} \beta$ : detection capability.

signal / noise $\geq 10$. Hernández et al. (2006) determined the LQ as $0.01 \mathrm{mg} / \mathrm{kg}$ for the multi-residue method, considering that at this level acceptable recovery and precision were obtained for all of the tested matrices. The LQ assessed by Zawiyah et al. (2007) in grape samples, considering six organochlorines and three pyrethroids, ranged from $0.01 \mathrm{mg} / \mathrm{kg}$ to $0.05 \mathrm{mg} / \mathrm{kg}$.

The values estimated for $\mathrm{CC} \alpha$ and $\mathrm{CC} \beta$ were lower than those obtained by Garcia-Chao et al. (2010). These authors performed the validation of systemic insecticides in honey and calculated CC $\alpha$ and CC $\beta$ based on calibration curves. Values between $0.41 \mathrm{mg} / \mathrm{kg}$ and $2.33 \mathrm{mg} \mathrm{kg}$ for CCa and from $0.83 \mathrm{mg} /$ $\mathrm{kg}$ to $4.83 \mathrm{mg} / \mathrm{kg}$ for CC $\beta$ were obtained. CCa is the limit at and above which it can conclude that a sample is non-compliant with a probability of error a corresponding to the rate of false noncompliant. CC $\beta$ is the smallest content of the analyte that can be detected, identified, or quantified in a sample with an error probability of $\beta$, corresponding to the false compliant (EUROPEAN..., 2002).

\subsection{Occurrence}

The occurrence of the 46 organohalogen residues in strawberry samples between 2009 and 2011 is shown in Table 8 . Considering the 186 samples analyzed in the period, 62 (33.3\%) had no organohalogens detected, and $114(61.3 \%)$ contained residues of these pesticides below the MRL. Nine (4.8\%) samples were classified as unsatisfactory, 7 (3.8\%) of them had residues of unauthorized pesticides for the strawberry culture, $1(0.5 \%)$ had residues above the MRL and 1 (0.5\%) exhibited both nonconformities.

Of the 94 samples analyzed in 2009, 67 had one or more residues of pesticides, which accounts for $71.3 \%$ of the total. 
Table 8. Occurrence of organohalogens residues in strawberry samples produced in the state of Minas Gerais between 2009 and 2011.

\begin{tabular}{|c|c|c|c|c|c|c|c|c|c|}
\hline \multirow[t]{2}{*}{ Year } & \multirow{2}{*}{$\begin{array}{c}\mathrm{N} \text { of analyzed } \\
\text { samples }\end{array}$} & \multicolumn{2}{|c|}{$\begin{array}{l}\text { Detection below } \\
\text { the MRL }\end{array}$} & \multicolumn{2}{|c|}{$\begin{array}{l}\text { Detection of not permitted } \\
\text { residues for the culture }\end{array}$} & \multicolumn{2}{|c|}{$\begin{array}{l}\text { Detection over } \\
\text { the MRL }\end{array}$} & \multicolumn{2}{|c|}{$\begin{array}{l}\text { Detection of not permitted residues } \\
\text { for the culture an over the MRL }\end{array}$} \\
\hline & & $\mathrm{N}$ & $\%$ & $\mathrm{~N}$ & $\%$ & $\mathrm{~N}$ & $\%$ & $\mathrm{~N}$ & $\%$ \\
\hline 2009 & 94 & 63 & 67.0 & 4 & 4.3 & 0 & 0.0 & 0 & 0.0 \\
\hline 2010 & 75 & 47 & 62.7 & 1 & 1.3 & 1 & 1.3 & 0 & 0.0 \\
\hline 2011 & 17 & 4 & 23.5 & 2 & 11.8 & 0 & 0.0 & 1 & 5.9 \\
\hline Total & 186 & 115 & 61.8 & 7 & 3.8 & 1 & 0.5 & 1 & 0.5 \\
\hline
\end{tabular}

$\mathrm{N}$ : number of samples, MRL: maximum residue limits.

Four $(4.3 \%)$ samples were not in accordance with the current legislation. Among the 75 analyzed samples analyzed in 2010, $49(65.3 \%)$ had residues of organohalogens; however, only two (2.6\%) of them were unsatisfactory. In 2011, 17 samples were analyzed and seven $(41.2 \%)$ had organohalogens residues. Three of them (17.6\%) were not in accordance with the Brazilian legislation. The samples were considered unsatisfactory when they had residues above the MRL and residues of unauthorized pesticides for strawberry culture.

It should be noted that the presence of unauthorized residues was, in most cases, more common than that in the cases with residues above the MRL, confirming the tendency obtained by the national monitoring programs.

In the same period of time, despite the lower number of strawberry samples, the PNCRC of the MAPA found unsatisfactory results for $13.3 \%$ of the 30 samples analyzed for 170 pesticides in the $2009 / 2010$ harvest and $51.1 \%$ of the 45 samples analyzed for 240 analytes in the 2010/2011 harvest. The unauthorized organohalogens found included cypermethrin, deltamethrin, and procloraz (BRASIL, 2010b, 2011a).

In 2009, 234 analytes were investigated in 128 strawberry samples by PARA, 49 (38.3\%) had unauthorized pesticides, 11 (8.6\%) had residues above the MLR, and 5 (3.9\%) exhibited both non-conformities (AGÊNCIA..., 2010). Considering the 112 strawberry samples and the 119 pesticides analyzed by the ANVISA Program in 2010, 58 (51.8\%) had residues of unauthorized residues, $3(2.7 \%)$ had residues detected at levels above the permissible limits, and 10 (8.9\%) exhibited both nonconformities (AGÊNCIA..., 2011).

Figure 3 shows the organohalogen compounds found in the 186 samples evaluated, highlighting the presence of procymidone, which was detected in 100 samples. Other relevant analytes detected were iprodione and lambda-cyhalothrin. It is noteworthy that $65.6 \%$ of the strawberry samples in 2009 and $67.9 \%$ in 2010 investigated by PARA showed residues of procymidone, confirming the profile obtained in this study.

In 2009 and 2010, the residues that were detected in levels below the MRL included iprodione, procymidone, lambdacialothrin, and difenoconazole. In 2011, procymidone was detected, but it was within the limit established by Brazilian legislation. The unauthorized residues for strawberries cultures detected were deltamethrin, procloraz, chlorfenapyr, and chlorotalonil in 2009; chlorfenapyr in 2010 and chlorfenapyr, chlorotalonil, and endosulfan (alpha, beta and sulphate) in 2011. Difenoconazole was detected in levels above the MRL

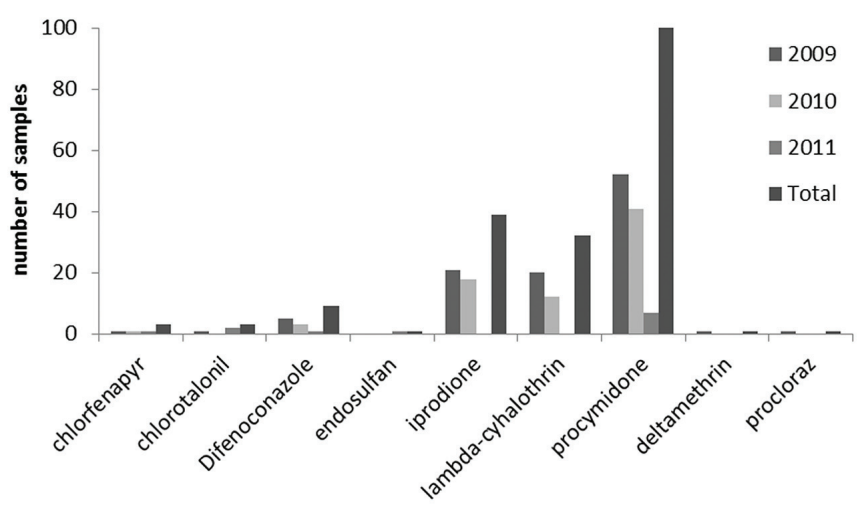

Figure 3. Organohalogens detected in strawberry samples in the years 2009, 2010 and 2011.

in the years of 2010 and 2011. Some samples contained more than one residue of pesticide, and in some cases four different organohalogen pesticides were detected.

Considering the USDA Pesticide Data Program from 1993 to 2003 , more than 100,000 samples were analyzed, and $65 \%$ of them were of fresh fruit and vegetables. Strawberry is among the fresh fruits and vegetables commodities that have been sampled for two or more years and had detectable residues in $90 \%$ or more of the samples (PUNZI et al., 2005).

The 2010 final report of the United Kingdom Pesticide Residues Committee (PRC) oversaw a monitoring program to check traces of pesticides residues in food and drink indicated that for the 96 analyzed samples, 85 (88.5\%) contained residues of these pesticides below the MRL and $76 \%$ of them contained more than one residue. In the present study, unauthorized residues and those above the MRL were not detected (PESTICIDE..., 2011).

In 2010, in Belgium, 1854 surveillance samples of fruit and vegetables were analyzed in the framework of the control program, and $31.2 \%$ were shown to be without residues of pesticides, $64.0 \%$ with residues at or below the MRL, and $4.8 \%$ with residues above the MRL. Like in previous years, imported products showed proportionally more MRL violations than the Belgium and European Union products. Main MRL violations in fruits were observed in strawberries imported from third world countries. However, the pesticide residues were different than those detected in this study (ethion, methomyl, chlorfenapyr, methomyl, and propargite) (BELGIUM, 2011). 


\section{Conclusions}

The method validated was fit for the purpose. The results of the strawberry samples highlighted the importance of monitoring and evaluating actions by the states, which are complementary tools for national programs. Therefore, the results presented in this paper contribute to food safety, indicating the importance of appropriate validated methods, the need for the promotion of good agricultural practices and that strawberry is a critical culture in terms of pesticide residues in Brazil.

\section{Acknowledgements}

The authors would like to acknowledge the financial support provided by the Brazilian agencies Conselho Nacional de Desenvolvimento Científico e Tecnológico (CNPq - 306559/2007-2 and 578643/2008-1) and Fundação de Amparo à Pesquisa do Estado de Minas Gerais (FAPEMIG - APQ00923-08).

\section{References}

AGÊNCIA NACIONAL DE VIGILÂNCIA SANITÁRIA - ANVISA. Programa de Análise de Resíduos de Agrotóxicos em Alimentos (PARA). Relatório de Atividades de 2001-2007. ANVISA, 2008.

AGÊNCIA NACIONAL DE VIGILÂNCIA SANITÁRIA - ANVISA. Programa de Análise de Resíduos de Agrotóxicos em Alimentos (PARA). Relatório de Atividades de 2009. ANVISA, 2010.

AGÊNCIA NACIONAL DE VIGILÂNCIA SANITÁRIA - ANVISA. Programa de Análise de Resíduos de Agrotóxicos em Alimentos (PARA). Relatório de Atividades de 2010. ANVISA, 2011.

AMARAL, E. H. Resíduos de agrotóxicos organofosforados: validação de métodos de cromatografia a gás e quantificação em produtos agrícolas. 2007. 134 f. Dissertação (Mestrado em Ciência de Alimentos)-Faculdade de Farmácia, Universidade Federal de Mina Gerais, Belo Horizonte, 2007.

AMBRUS, A. Worked example for validation of a multi-residue method. In: FAJGELP, A.; AMBRUS. A. (Ed.). Principles and practices of method validation. Workshop on the principles and practices of method validation. Budapest: Royal Society of Chemistry, 2000, n. 256, p. 157-175.

ANASTASSIADES, M. et al. Fast and easy multiresidue method employing acetonitile extraction/partitioning and "dispersive solid-phase extraction" for the determination of pesticide residues in produce. Journal of AOAC International, v. 86, p. 412-431, 2003. PMid:12723926.

ASSOCIAÇÃO BRASILEIRA DE NORMAS TÉCNICAS - ABNT. NBR ISO/IEC 17025: Requisitos gerais para a competência de laboratórios de ensaio e calibração. 2. ed. ABNT, 2005. 31 p.

BELGIUM. Federal Agency for the Safety of the Food Chain - FASFC. Controls of pesticide residues in food Belgium 2010: results of the official controls in accordance to Regulation (CE) N³96/2005 and Commission Regulation (EC) No 901/2009. Belgium: FASFC, 2011.9 p.

BERRADA, H. et al. Surveillance of pesticide residues in fruits from Valencia during twenty months (2004/05). Food Control, v. 21, p. 36-44, 2010. http://dx.doi.org/10.1016/j.foodcont.2009.03.011

BRASIL. Ministério da Agricultura, Pecuária e Abastecimento - MAPA. Secretaria de Defesa Agropecuária. Instrução normativa no 8, de 29 de abril de 2010. Diário Oficial da República Federativa do Brasil, Brasília, DF, 3 maio 2010a. p. 24-30.

BRASIL. Ministério da Agricultura, Pecuária e Abastecimento - MAPA. Secretaria de Defesa Agropecuária. Instrução normativa no 22, de 8 de setembro de 2010. Diário Oficial da República Federativa do Brasil, Brasília, DF, 10 set. 2010b. p. 3-4.

BRASIL. Ministério da Agricultura, Pecuária e Abastecimento - MAPA. Secretaria de Defesa Agropecuária. Instrução normativa n 26, de 8 de outubro de 2010. Diário Oficial da República Federativa do Brasil, Brasília, DF, 14 out. 2010c.

BRASIL. Ministério da Agricultura, Pecuária e Abastecimento - MAPA. Secretaria de Defesa Agropecuária. Instrução normativa n 40 , de 11 de novembro de 2011. Diário Oficial da República Federativa do Brasil, Brasília, DF, 16 nov. 2011a.

BRASIL. Ministério da Agricultura, Pecuária e Abastecimento - MAPA. Manual de garantia da qualidade analítica. Brasília: MAPA, 2011 b. $227 \mathrm{p}$.

CARDOSO, M. H. W. M. et al. Validação de método para determinação de resíduos de agrotóxicos em tomate: uma experiência laboratorial. Ciência e Tecnologia de Alimentos, v. 30, p. 63-72, 2010. Suplemento 1.

CHEN, Z. M.; WANG Y. H. Chromatographic methods for the determination of pyrethrin and pyrethroid pesticide residues in crops, foods and environmental samples. Journal of Chromatography A, v. 754, p. 367-395, 1996. http://dx.doi. org/10.1016/S0021-9673(96)00490-6

CIESLIK, E. et al. Evaluation of QuEChERS method for the determination of organochlorine pesticide residues in selected groups of fruits. Food Chemistry, v. 125, p. 773-778, 2011. http:// dx.doi.org/10.1016/j.foodchem.2010.09.019

CODEX ALIMENTARIUS. Recommended methods of sampling for the determination of pesticide residues for compliance with MRLs. Rome: FAO, CAC/GL 33, 1999.

COLUMÉ, A. et al. Selective enrichment of 17 pyrethroids from lyophilised agricultural samples. Journal of Chromatography A, v. 912, p. 83-90, 2001. http://dx.doi.org/10.1016/S00219673(01)00546-5

EUROPEAN COMMISSION. Method validation and quality control procedures for pesticide residue analysis in food and feed (doc. $\mathrm{N}^{\circ}$ SANCO/10684/2009). 2010. 40 p.

EUROPEAN COMMISSION. Commission decision 2002/657/EC of 12 August 2002. Implementing Council Directive 96/23/EC concerning performance of analytical methods and the interpretation of results. Official Journal of the European Communities, 2002. L 221/8.

GARCIA-CHAO, M. et al. Validation of an off line solid phase extraction liquid chromatography-tandem mass spectrometry method for the determination of systemic insecticide residues in honey and pollen samples collected in apiaries from NW Spain. Analytica Chimica Acta, v. 672, p. 107-113, 2010. PMid:20579498. http://dx.doi.org/10.1016/j.aca.2010.03.011

GONZÁLEZ, F. J. E. et al. Matrix-effects of vegetable commodities in electron-capture detection applied to pesticide multiresidue analysis. Journal of Chromatography A, v. 966, p. 155-165, 2002. http://dx.doi.org/10.1016/S0021-9673(02)00707-0

GORENSTEIN, O. Monitoramento de resíduos de agrotóxicos realizado pela CEAGESP no período de dezembro de 2006 a maio de 2007. Informações Econômicas, v.38, p. 32-39, 2008. Disponível em: <http://www.iea.sp.gov.br>. Acesso em 01 abr. 2010.

HERNÁNDEZ, F. et al. Multiresidue liquid chromatography tandem mass spectrometry determination of 52 non gas chromatography- 
amenable pesticides and metabolites in different food commodities. Journal of Chromatography A, v. 1109, p. 242-252, 2006. PMid:16445927. http://dx.doi.org/10.1016/j.chroma.2006.01.032

IMOTO, M. N.; FONTOURA, P. S. G.; FREITAS, R. J. S. Validação de método multiresíduo para análise de pesticidas organohalogenados em maçãs. Revista do Instituto Adolfo Lutz, v. 63, n. 2, p. 186192, 2004.

INSTITUTO NACIONAL DE METROLOGIA, NORMALIZAÇÃO E QUALIDADE INDUSTRIAL - INMETRO. DOQ-CGCRE-008. Orientações sobre validação de métodos de ensaios químicos. Rio de Janeiro: INMETRO, 2010. 35 p.

KEALEY, D.; HAINES, P. J. Instant Notes in Analytical Chemistry. Oxford: BIOS Scientific Publishers, 2002. 353 p.

KRISTENSON, E. M. et al. Miniaturized automated matrix solidphase dispersion extraction of pesticides in fruit followed by chromatographic-mass spectrometric analysis. Journal of Chromatography A, v. 917, p. 277-286, 2001. http://dx.doi. org/10.1016/S0021-9673(01)00677-X

LENTZA-RIZOS, C.; AVRAMIDES, E. J.; VISI, E. Determination of residues of endosulfan and five pyrethroid inseticides in virgin oil using gas chromatography with electron-capture detection. Journal of Chromatography A, v. 921, p. 298-304, 2001. http://dx.doi. org/10.1016/S0021-9673(01)00874-3

MENEZES, A. F.; SANTOS, F. N.; PEREIRA, P.A. P. Development, validation and application of a methodology based on solid-phase micro extraction followed by gas chromatography coupled to mass spectrometry (SPME/GC-MS) for the determination of pesticide residues in mangoes. Talanta, v. 81, p. 346-354, 2010. PMid:20188930. http://dx.doi.org/10.1016/j.talanta.2009.12.008

NETHERLANDS. Ministry of Public Health, Welfare and Sport. Analytical Methods for Pesticide Residues in Foodstuffs. 6th ed. Amsterdam: RIVM, 1996.

PINHO, G. P. et al. Efeito de matriz na quantificação de agrotóxicos por cromatografia gasosa. Química Nova, v. 32, n 4, p. 987-995, 2009. http://dx.doi.org/10.1590/S0100-40422009000400030

PESTICIDE RESIDUES COMMITTEE - PRC. Annual Report of the Pesticide Residues Committee 2010. New York: Chemicals Regulation Directorate of The Health and Safety Executive, 2011. $37 \mathrm{p}$.

POOLE, C. F. Matrix-induced response enhancement in pesticide residue analysis by gas chromatography. Journal of Chromatography A, v. 1158, p. 241-250, 2007. PMid:17241638. http://dx.doi. org/10.1016/j.chroma.2007.01.018

PRZYBYLSKI, C.; HOMMET, F. Evaluation of some parameters affecting troublesome pesticide analysis in gas chromatographyion-trap mass spectrometry. Journal of Chromatography A, v. 1201, p. 78-90, 2008. PMid:18555259. http://dx.doi.org/10.1016/j. chroma.2008.05.081
PUNZI, J. S. et al. USDA pesticide data program: pesticide residues on fresh and processed fruit and vegetables, grains, meats, milk, and drinking water. Outlooks on Pest Management. p. 131-137, 2005.

RIBANI, M. et al. Validação em métodos cromatográficos e eletroforéticos. Quimica Nova, v. 27, n. 5, p. 771-780, 2004.

SANCHES, S. M. et al. Pesticidas e seus respectivos riscos associados à contaminação da água. Revista de Ecotoxicologia e Meio Ambiente, v. 13, p. 53-58, 2003.

SCHENCK, F. J.; LEHOTAY, S. J. Does further clean-up reduce the matrix enhancement effect in gas chromatographic analysis of pesticide residues in food?. Journal of Chromatography A, v. 868, p. 51-61, 2000. http://dx.doi.org/10.1016/S0021-9673(99)01137-1

SOUZA, S. V. C. Procedimento para validação intralaboratorial de métodos de ensaio: delineamento e aplicabilidade em análises de alimentos. 2007. 296 f. Tese (Doutorado em Ciências de Alimentos)Faculdade de Farmácia, Universidade Federal de Minas Gerais, Belo Horizonte, 2007.

SOUZA, S. V. C.; JUNQUEIRA, R. G. A procedure to assess linearity by ordinary least squares method. Analytica Chimica Acta, v. 552; p. 25-35, 2005. http://dx.doi.org/10.1016/j.aca.2005.07.043

SSEBUGERE, P. et al. Organochlorine pesticides in soils from south-western Uganda. Chemosphere, v. 78, P. 1250 1255, 2010. PMid:20064653. http://dx.doi.org/10.1016/j. chemosphere.2009.12.039

THOMPSON, M.; ELLISON, S. L. R.; WOOD, R. Harmonized guidelines for single-laboratory validation of methods of analysis. Pure and Applied Chemistry, v. 74, p. 835-855, 2002. http://dx.doi. org/10.1351/pac200274050835

UNITED STATES DEPARTMENT OF AGRICULTURE - USDA. Pesticide Data Program (PDP). Annual Summary, Calendar Year 2008. December 2009. Disponível em: <http:// www.ams.usda.gov/ pdp >. Acesso em: 10 fev. 2010.

VAN LOCO, J.; BEERNAERT, H. An alternative method validation strategy for the European Decision 2002/657/EC. In: PROCEEDINGS OF EUROPEAN FOOD CHEMISTRY, 12, 2003, Brugges. Proceedings... Brugges: European Food Chemistry, 2003. p. 91-94.

VIEIRA, H. P.; NEVES, A. A.; QUEIROZ, M. E. L. R. Otimização e validação da técnica de extração líquido-líquido com partição em baixa temperatura (ELL-PBT) para piretróides em água e análise por CG. Química Nova, v. 30, n. 3, p. 535-540, 2007. http://dx.doi. org/10.1590/S0100-40422007000300006

ZAWIYAH, S. et al. Determination of organochlorine and pyrethroid pesticides in fruit and vegetables using SAX/PSA clean-up column. Food Chemistry, v. 102, p. 98-103, 2007. http://dx.doi. org/10.1016/j.foodchem.2006.05.003

ZROSTLÍKOVÁ, J. et al. Performance of programmed temperature vaporizer, pulsed splitless and on-column injection techniques in analysis of pesticide residues in plant matrices. Journal of Chromatography A, v. 937, p. 73-86, 2001. http://dx.doi. org/10.1016/S0021-9673(01)01308-5 